\title{
IN-FURROW INOCULATION OF SOYBEAN AS ALTERNATIVE TO FUNGICIDE AND MICRONUTRIENT SEED TREATMENT ${ }^{(1)}$
}

\author{
Rubens José Campo ${ }^{(2)}$, Ricardo Silva Araujo(2), Fábio Luís \\ Mostasso $^{(2)}$ \& Mariangela Hungria ${ }^{(2,3)}$
}

\begin{abstract}
SUMMARY
Soybean is a major grain crop in Brazil, and yields can be considerably improved by inoculation with selected Bradyrhizobium strains. However, the incompatibility between inoculation and seed treatments with fungicides and micronutrients represents a major barrier to the achievement of high rates of biological $\mathrm{N}_{2}$ fixation. Inoculation practices that can alleviate the negative effects of agrochemicals must therefore be found and in-furrow inoculation seems to be an attractive alternative. This study reports the results of seven field experiments conducted in three growing seasons in Brazil; three in soils previously cropped with inoculated soybean $\left(>10^{4}\right.$ cells $\mathrm{g}^{-1}$ of soil of Bradyrhizobium), and four in areas where the crop was sown for the first time $\left(<10^{2}\right.$ cells $\mathrm{g}^{-1}$ of soil of Bradyrhizobium). The compatibility with fungicides and micronutrients was compared in seeds inoculated with peat or liquid inoculants, or treated with different doses of liquid inoculant in-furrow. In areas with established Bradyrhizobium populations, seed-applied agrochemicals did generally not affect nodulation, but also did not increase yields, while inoculation always increased $\mathrm{N}$ grain accumulation or yield, and $\mathrm{N}$ fertilizer decreased both nodulation and yield. Where soybean was sown for the first time, the seed treatment with agrochemicals affected nodulation when applied together with peat or liquid inoculant. In-furrow inoculation alleviated the effects of seed treatment with agrochemicals; the best performance was achieved with high Bradyrhizobium cell concentrations, with up to 2.5 million cells seed ${ }^{-1}$.
\end{abstract}

Index terms: Glycine $\max$ [L. (Merrill.)], Bradyrhizobium, inoculant.

\footnotetext{
(1) Received for publication in August 2009 and approved in May 2010.

(2) Embrapa Soja, Caixa Postal 231, CEP 86001-970 Londrina (PR). E-mails: rjcampo@cnpso.embrapa.br; rsaraujo@totalbiotecnologia.com.br; flmostasso@gmail.com; hungria@cnpso.embrapa.br

(3) Conselho Nacional de Desenvolvimento Científico e Tecnológico (CNPq-MCT), Brasília, Federal District, Brazil. E-mail: hungria@cnpso.embrapa.br
} 


\title{
RESUMO: INOCULAÇÃO NO SULCO DE PLANTIO DA SOJA COMO ALTERNATIVA PARA O TRATAMENTO DE SEMENTE COM FUNGICIDAS E MICRONUTRIENTES
}

\begin{abstract}
A soja é a principal cultura de grãos do Brasil e pode se beneficiar fortemente da inoculação com estirpes selecionadas de Bradyrhizobium. Contudo, a incompatibilidade entre inoculantes e o tratamento de sementes com fungicidas e micronutrientes representa um fator limitante para alcançar taxas elevadas de fixação biológica do N. Desse modo, práticas de inoculação que possam minimizar os efeitos negativos desses produtos devem ser procuradas, e a inoculação no sulco aparece como uma alternativa atraente. Este estudo relata o resultado de sete experimentos de campo conduzidos no Brasil por três safras: três em solos previamente cultivados com soja (> $10^{4}$ células $\mathrm{g}^{-1}$ de solo de Bradyrhizobium) e quatro em áreas cultivadas pela primeira vez $\left(<10^{2}\right.$ células células $\mathrm{g}^{-1}$ de solo de Bradyrhizobium). A compatibilidade com fungicidas e micronutrientes foi comparada com as sementes inoculadas com inoculantes turfosos ou líquidos, ou recebendo diferentes doses de inoculante líquido no sulco. Em áreas com populações estabelecidas de Bradyrhizobium, em geral, os agrotóxicos aplicados nas sementes não alteraram a nodulação, mas também não beneficiaram os rendimentos, enquanto a inoculação sempre incrementou o $\mathrm{N}$ acumulado nos grãos ou o rendimento, e o $\mathrm{N}$-fertilizante diminuiu tanto a nodulação como o rendimento. Em áreas cultivadas pela primeira vez, o tratamento com o fungicida alterou a nodulação quando aplicado em conjunto com inoculante turfoso ou líquido nas sementes. A inoculação no sulco diminuiu o efeito deletério dos tratamentos das sementes, e os melhores desempenhos foram obtidos com altas concentrações de células de Bradyrhizobium, de até 2,5 milhões de células semente-1.
\end{abstract}

Termos de indexação: Glycine max [L. (Merrill.)], Bradyrhizobium, inoculante.

\section{INTRODUCTION}

Soybean [Glycine $\max ($ L.) Merr.] can obtain N from the symbiotic association with Bradyrhizobium, but the efficiency of the biological process in the tropics is often negatively affected by several factors (Hungria \& Vargas, 2000; Hungria et al., 2006). The lack of compatibility among micronutrients, fungicides and inoculants is a major problem for soybean cultivation in Brazil. The population of selected inoculant strains on the seed surface must be increased in order to supply the necessary amounts of $\mathrm{N}$ required by more productive cultivars, but benefits may be restricted because of the toxicity of the chemical products on the inoculated bacteria.

The intensification of soybean cultivation has resulted in reduced availability of Mo in soils, and yield increases are observed when Mo is supplied to the crop (Campo et al., 2006; Hungria et al., 2007). Seed treatment with saline or acidic Mo sources has been recommended (Embrapa, 2006), which however affects the rhizobia and survival of inoculated bacteria on the seeds (Bordeleau \& Prévost, 1994; Albino \& Campo, 2001; Hungria et al., 2007).

Certain diseases seriously affect soybean yield in Brazil and are major concerns for the farmers (Henning et al., 1997; Embrapa, 2006). Besides, most soybean pathogens are seed-borne, and while highvigor seeds are ideal alternatives for areas where diseases are not a serious threat (Hungria et al., 2007), seed treatment with one or more fungicides has been widely applied as a low-cost control of fungal diseases (Henning et al., 1997).

Seed treatment with fungicides and micronutrients and inoculation with larger bradyrhizobia populations to meet the $\mathrm{N}$ demand of high-yielding cultivars have stimulated the development of alternative inoculation technologies. This study presents results of field experiments conducted in Brazil to evaluate the technology of liquid in-furrow inoculation of soybean seeds treated with fungicides and micronutrients, in comparison with the traditional peat or liquid inoculants applied to the seed.

\section{MATERIAL AND METHODS}

Three experiments were carried out in soils with pre-established Bradyrhizobium soybean populations, in Londrina, State of Paraná (2000/01, 2001/02, and 2002/03), Brazil, and four in soils without established Bradyrhizobium soybean populations, in Avaré (2000/ 01 and 2001/02) and Taciba (2002/03), State of São Paulo, and Jaciara, State of Mato Grosso (2001/02) (Table 1). Soil populations of bradyrhizobia (Table 1) were estimated in the $0-10 \mathrm{~cm}$ layer by the technique of the most probable number (MPN) (Andrade \& Hamakawa, 1994), based on counts on soybean plants (cultivar Embrapa 48). Soil chemical properties were 
Table 1. Geographic coordinates, populations of soybean/Bradyrhizobium, and chemical characteristics of the soils at the experimental sites in Brazil

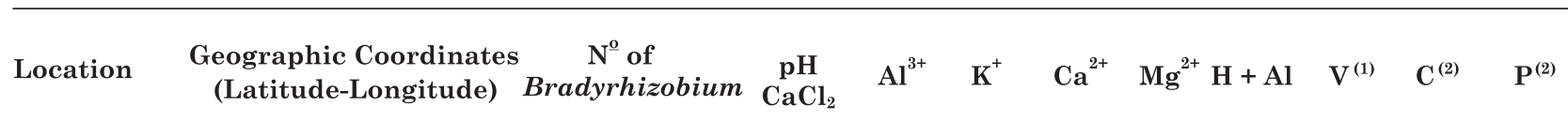

\begin{tabular}{|c|c|c|c|c|c|c|c|c|c|c|c|}
\hline & \multicolumn{3}{|c|}{ cells $\mathrm{g}$ of soil ${ }^{-1}$} & \multicolumn{5}{|c|}{$\mathrm{cmol}_{\mathrm{c}} \mathrm{dm}^{-3}$} & \multirow[t]{2}{*}{$\%$} & \multirow[t]{2}{*}{$\mathrm{g} \mathrm{dm}^{-3}$} & \multirow[t]{2}{*}{$\mathrm{mg} \mathrm{dm}{ }^{-3}$} \\
\hline \multicolumn{9}{|c|}{ Areas with naturalized populations of soybean bradyrhizobia } & & & \\
\hline Londrina 00/01 & $23^{\circ} 18^{\prime} \mathrm{S} 51^{\circ} 09^{\prime} \mathrm{W}$ & $2.2 \times 10^{4}$ & 5.6 & 0.00 & 0.54 & 5.00 & 1.90 & 3.3 & 69 & 19.0 & 24.5 \\
\hline Londrina 01/02 & Same & $6.2 \times 10^{4}$ & 5.3 & 0.00 & 0.58 & 5.10 & 1.82 & 4.6 & 62 & 15.7 & 15.9 \\
\hline Londrina $02 / 03$ & Same & $1.1 \times 10^{5}$ & 5.3 & 0.00 & 0.63 & 4.91 & 1.97 & 3.9 & 66 & 15.2 & 16.7 \\
\hline \multicolumn{12}{|c|}{ Areas without naturalized populations of soybean bradyrhizobia } \\
\hline Avaré 00/01 & $23^{\circ} 05^{\prime} \mathrm{S} 48^{\circ} 55^{\prime} \mathrm{W}$ & $<10^{1}$ & 5.5 & 0.00 & 0.10 & 2.00 & 1.10 & 3.3 & 50 & 13.0 & 13.9 \\
\hline Avaré 01/02 & Same & $<10^{1}$ & 5.4 & 0.00 & 0.09 & 4.61 & 1.77 & 3.2 & 67 & 14.9 & 6.8 \\
\hline Taciba 02/03 & $22^{\circ} 23^{\prime} \mathrm{S} 51^{\circ} 17^{\prime} \mathrm{W}$ & $<10^{1}$ & 4.4 & 0.24 & 0.29 & 1.01 & 0.41 & 3.9 & 30 & 12.6 & 15.7 \\
\hline Jaciara 01/02 & $15^{\circ} 57^{\prime} \mathrm{S} 54^{\circ} 58^{\prime} \mathrm{W}$ & $<10^{2}$ & 4.8 & 0.06 & 0.08 & 1.21 & 0.36 & 5.1 & 24 & 21.4 & 9.7 \\
\hline
\end{tabular}

(1) Soil base saturation. ${ }^{(2)}$ Values of total $\mathrm{C}$ and available P in the soil.

determined according to standard methods (Pavan et al., 1992) (table 1).

Fifty days before starting the experiments, soil $\mathrm{pH}$ values were determined and lime was applied to alleviate acidity, at a rate estimated to reach a base saturation of 50-70\%, according to the recommendation for the location of the experiments, to raise the $\mathrm{pH}$ to 5.0-5.5. Before planting, the areas were fertilized according to the standard recommendation: $300 \mathrm{~kg} \mathrm{ha}^{-1}$ of N-P-K (0-28-20); other macro and micronutrients (except Mo and Co) were supplied when necessary, according to the soil analysis.

Field plots of $4.0 \mathrm{~m}$ (length) x $5.0 \mathrm{~m}$ (width), with nine rows $0.5 \mathrm{~m}$ apart from one another, with small terraces of $1.0 \mathrm{~m}$ in the interspaces to prevent contamination by surface run-off containing bacteria or fertilizer. Plant density was around 300,000 plants ha-1 of soybean cultivar Embrapa 48. Insects were controlled with biological and chemical insecticides and weeds with herbicides, according to the annual technical recommendation for the crop (Embrapa, 2006). None of the experiments was irrigated and, therefore, growth was conditioned by rainfall. All other cultural practices followed the regional recommendations for soybean of the experimental sites.

Treatments aimed at comparing the performance of seed-applied peat and liquid inoculants with the application of liquid inoculant in the planting furrow, using untreated seeds or seeds treated with the fungicides and micronutrients tested in a separate experiment. Peat seed inoculation served as standard technique, to which the in-furrow application of increasing doses of liquid inoculant was compared. Peat inoculation of fungicide and micronutrienttreated or untreated seeds was included in all experiments but those of 2002/2003 in Londrina, PR, and Taciba, SP, where only a single dose of liquid inoculant was used to inoculate either the seeds or the furrow. A control treatment inoculated and fertilized with $\mathrm{N}$ at $200 \mathrm{~kg} \mathrm{ha}^{-1} \mathrm{~N}$ (urea, $50 \%$ applied at sowing and $50 \%$ applied 30 days after seedling emergence) and non-inoculated control treatment were included in all experiments.

The inoculants contained a proportional (1:1) mixture of strains SEMIA 5079 (=CPAC 15) and SEMIA 5080 (=CPAC 7) of Bradyrhizobium japonicum, both effective and recommended for soybean inoculation in Brazil. In each experiment the amounts of peat or liquid inoculants used followed the official recommendation of the Ministry of Agriculture (Ministério da Agricultura, Pecuária e Abastecimento) for soybean in Brazil at the time the experiments were performed, estimated at $3 \times 10^{5}$ cells of Bradyrhizobium seed ${ }^{-1}$. The volume of liquid inoculant to be sprayed was estimated on the basis of the number of seeds per linear meter in the planting furrow, so as to deliver the officially recommended dose of inoculant per $50 \mathrm{~kg}$ of seeds. Increasing doses of liquid in-furrow inoculant were tested in some of the experiments, to determine the benefits of higher inoculum densities.

For seed treatment with peat inoculant, a $10 \%$ $(\mathrm{w} / \mathrm{v})$ sucrose solution was used to increase inoculant adhesion, and was applied at a rate of $300 \mathrm{~mL} 50 \mathrm{~kg}^{-1}$ seeds in all experiments, as recommended for soybean (Hungria et al., 2007). Seeds were inoculated with peat inoculant immediately before sowing by first applying the sucrose solution to the seeds, followed by fungicides, then micronutrients, and finally the peat inoculant. After mixing, seeds were air-dried in the shade for 15 min and hand-sown within a maximum of $4 \mathrm{~h}$. 
For the in-furrow treatment, the liquid inoculant was sprayed into the furrow before sowing, either by hand (Jaciara), by means of a coastal sprayer with a fan nozzle diagonally into the furrow, or mechanically (Londrina, Avaré, and Taciba), by means of a tractor spraying equipment adapted to a no-till planter. In this last case, the inoculant/water mixture was distributed by plastic hoses ending in aluminum rods fitted with fan nozzles in diagonal direction to the planting furrow. In all cases, the final volume (inoculant plus water) of liquid sprayed was equivalent to $50 \mathrm{~L} \mathrm{ha}^{-1}$. Non-inoculated controls received the same volume of water, without inoculant.

Fungicides employed were Tolylfluanid, at $0.5 \mathrm{~g} \mathrm{~kg}^{-1}$ of a.i on the seeds + Methyl Tiofanate, at $0.4 \mathrm{~g} \mathrm{~kg}^{-1}$ of a.i on the seeds. Micronutrients (Mo and Co) were supplied as liquid commercial formulations, in volumes necessary to deliver $20 \mathrm{~g} \mathrm{ha}^{-1}$ of Mo and $2 \mathrm{~g} \mathrm{ha}^{-1}$ of Co for all treatments, in all experiments.

To evaluate nodulation, ten plants per replication were randomly collected (avoiding areas designated for grain harvesting) at the V4 stage [four nodes on the main stem with fully developed leaves, beginning at the unifoliolate node, scale of Fehr \& Caviness (1977)],. In the laboratory, roots were carefully washed and dried to constant weight in a forced-air dryer at $65{ }^{\circ} \mathrm{C}$. After drying, nodules were removed from roots and dried again, for evaluation of nodule number and dry weight. In some experiments, at the $\mathrm{R}^{2}$ stage [full bloom; open flower at one of the two uppermost nodes on the main stem with a fully developed leaf), scale of Fehr \& Caviness, 1977)], shoots of 10 plants were harvested to determine shoot dry weight and $\mathrm{N}$ tissue content. Grain yield at physiological maturity was assessed based on the six central rows of each plot (6 $\mathrm{m}^{2}$ area), and data were corrected to a moisture content of $13 \%$, after determination of the humidity level in a grain moisture tester (Vurroughf 700). N grain concentration was estimated after Kjeldahl digestion and determined by an automatic $\mathrm{N}$-analyzer (Kjeltec Auto Sampler System 1035 Analyzer, Tecator, Sweden).

The experiments were arranged in a complete randomized block design with six blocks. Block and year effects were considered random, whereas treatment effects were considered fixed. The data were analyzed using SAS for PC statistical package, using PROC GLM. All assumptions required by the analysis of variance (ANOVA) were verified. The error normality, according to the experimental model design, was evaluated by Shapiro-Wilk's test, the variance of homogeneity by Burr-Foster's test, and the non-additivity of the model by Tukey's method. Coefficient of skewness and kurtosis were also checked. Treatment means were compared by the Fisher LSD test with $\mathrm{p} \leq 0.05$.

\section{RESULTS}

\section{Soils with pre-established Bradyrhizobium populations}

Three experiments were conducted in soils with pre-established populations of Bradyrhizobium in Londrina, Paraná. In 2000/01, as often observed in soils with established bradyrhizobia populations, the peat or liquid inoculant treatments did not increase nodule number (NN) or dry weight (NDW) when compared to the non-inoculated treatment (Table 2). Seed treatments with agrochemicals did not affect any of the parameters evaluated, compared to the standard peat inoculation (PI). N fertilizer decreased NDW

Table 2. Nodule number (NN) and dry weight (NDW) at the V4 stage, $\mathrm{N}$ grain content (NGC), total $\mathrm{N}$ grain content (TNG), and grain yield at the harvest of soybean inoculated with peat (PI) or liquid (LI) inoculant, with or without seed treatment (ST) with fungicides and micronutrients ${ }^{(1)}$. Experiment conducted in Londrina, Paraná, in the 2000/2001 growing season, in a soil with pre-established soybean/Bradyrhizobium population $\left(2.2 \times 10^{4} \text { cells g }^{-1} \text { of soil }\right)^{(2)}$

\begin{tabular}{|c|c|c|c|c|c|}
\hline Treatment & NN & NDW & NCG & TNG & Yield \\
\hline & $\mathrm{N}^{\underline{o}} /$ plant & $\mathrm{mg} /$ plant & $\mathrm{mg} \mathrm{g}^{-1}$ & $\mathrm{~kg} \mathrm{ha}{ }^{-1} \mathrm{~N}$ & $\mathrm{~kg} \mathrm{ha-1}$ \\
\hline Non-inoculated control & $16 \mathrm{ab}$ & $30 a b$ & $53.6 \mathrm{c}$ & $190 \mathrm{~cd}$ & $3,545 \mathrm{ab}$ \\
\hline $\mathrm{N}$ control $\left(200 \mathrm{~kg} \mathrm{ha}^{-1} \mathrm{~N}\right)$ & $13 \mathrm{~b}$ & $10 \mathrm{c}$ & $53.4 \mathrm{c}$ & $179 \mathrm{e}$ & $3,343 \mathrm{~b}$ \\
\hline PI & $17 \mathrm{ab}$ & $25 \mathrm{ab}$ & $53.9 \mathrm{c}$ & $185 \mathrm{de}$ & $3,436 \mathrm{ab}$ \\
\hline $\mathrm{PI}+\mathrm{ST}$ & $18 \mathrm{a}$ & $25 \mathrm{ab}$ & $58.2 \mathrm{ab}$ & $202 \mathrm{bcd}$ & $3,477 \mathrm{ab}$ \\
\hline $\mathrm{LI}(150 \mathrm{~mL})+\mathrm{ST}$ & $16 \mathrm{ab}$ & $27 \mathrm{ab}$ & $58.2 \mathrm{ab}$ & $205 \mathrm{bc}$ & $3,523 \mathrm{ab}$ \\
\hline $\mathrm{LI}(300 \mathrm{~mL})+\mathrm{ST}$ & $19 \mathrm{a}$ & $32 \mathrm{a}$ & $58.9 \mathrm{ab}$ & $197 \mathrm{~cd}$ & $3,344 \mathrm{~b}$ \\
\hline $\mathrm{LI}(600 \mathrm{~mL})+\mathrm{ST}$ & $18 \mathrm{a}$ & $28 \mathrm{ab}$ & $59.0 \mathrm{ab}$ & $217 \mathrm{ab}$ & 3,678 a \\
\hline $\mathrm{LI}(1,200 \mathrm{~mL})+\mathrm{ST}$ & $15 \mathrm{ab}$ & $24 \mathrm{ab}$ & $59.3 \mathrm{a}$ & $218 \mathrm{ab}$ & 3,675 a \\
\hline $\mathrm{LI}(2,400 \mathrm{~mL})+\mathrm{ST}$ & $14 \mathrm{ab}$ & $20 \mathrm{~b}$ & $59.5 \mathrm{a}$ & $223 \mathrm{a}$ & $3,751 \mathrm{a}$ \\
\hline $\mathrm{CV}(\%)$ & 10.9 & 16.3 & 2.9 & 6.8 & 6.6 \\
\hline
\end{tabular}

(1) Peat inoculant was applied to the seed surface, according to the standard inoculation for the growing season, resulting in 300,000 cells seed ${ }^{-1}$; liquid inoculant was sprayed into the planting furrow at $150\left(300,000 \mathrm{cells}^{\mathrm{seed}} \mathrm{s}^{-1}\right), 300,600,1200$, and $^{2}$ $2400 \mathrm{~mL} \mathrm{ha}^{-1}$, in a final volume of $50 \mathrm{~L} \mathrm{ha}^{-1}$ (inoculant + water). Fungicides and micronutrients are described in the Materials and Methods section. ${ }^{(2)}$ Means $(n=6)$ in the same column followed by different letters are significantly different ( $\leq \leq 0.05$, Fisher LSD test). 
and $\mathrm{N}$ grain content (NGC) in comparison to all other treatments and resulted in lower yields (Table 2). However, yield increases were observed with the three highest doses of in-furrow liquid inoculant (LI), when compared to the $\mathrm{N}$ control.

In 2001/02, seed treatment with fungicides affected NN when seeds were inoculated with PI or in-furrow LI, except at the highest LI dose (Table 3). All rates of in-furrow applied liquid inoculant promoted significantly higher grain yields than both the noninoculated and $\mathrm{N}$ fertilizer controls, and were as effective as the standard peat inoculant for seeds treated with agrochemicals (Table 3).
In 2002/03, when treatments included only seed or furrow-applied LI, seed inoculation significantly increased NDW and NGC over the non-inoculated control (Table 4). All inoculant treatments significantly increased yield compared to the $\mathrm{N}$ control, but not when compared to the non-inoculated control. Seed treatment with fungicides only affected NGC when LI was seed-applied (Table 4); this may reflect the deleterious effect of the agrochemical on inoculated bacteria. None of the treatments resulted in higher yields than the non-inoculated control; this situation is commonly observed in soils with a large population of soybean/ Bradyrhizobium.

Table 3. Nodule number (NN) and dry weight (NDW) at the V4 stage, $\mathrm{N}$ grain content (NGC), total N grain content (TNG), and grain yield at the harvest of soybean inoculated with peat (PI) or liquid (LI) inoculant, with or without seed treatment (ST) with fungicides and micronutrients ${ }^{(1)}$. Experiment conducted in Londrina, Paraná, in the 2001/2002 growing season, in a soil with pre-established soybean/Bradyrhizobium population $\left(6.2 \times 10^{4} \text { cells g }^{-1} \text { of soil }\right)^{(2)}$

\begin{tabular}{|c|c|c|c|c|c|}
\hline Treatment & NN & NDW & NCG & TNG & Yield \\
\hline & $\mathrm{N}^{\mathrm{o}} /$ plant & $\mathrm{mg} /$ plant & $\mathrm{mg} \mathrm{g}^{-1}$ & $\mathrm{~kg} \mathrm{ha} \mathrm{h}^{-1} \mathrm{~N}$ & $\mathrm{~kg} \mathrm{ha}^{-1}$ \\
\hline Non-inoculated control & $6 \mathrm{c}$ & $7 \mathrm{c}$ & $60.4^{\mathrm{ns}}$ & $193 \mathrm{c}$ & $3,189 \mathrm{~b}$ \\
\hline $\mathrm{N}$ control $\left(200 \mathrm{~kg} \mathrm{ha}^{-1} \mathrm{~N}\right)$ & $8 \mathrm{bc}$ & $8 \mathrm{bc}$ & 60.2 & $200 \mathrm{bc}$ & $3,311 \mathrm{~b}$ \\
\hline PI & $14 \mathrm{a}$ & $18 \mathrm{a}$ & 61.0 & $217 \mathrm{abc}$ & $3,564 \mathrm{ab}$ \\
\hline $\mathrm{PI}+\mathrm{ST}$ & $8 \mathrm{bc}$ & $17 \mathrm{a}$ & 60.0 & $229 \mathrm{ab}$ & $3,827 \mathrm{a}$ \\
\hline $\mathrm{LI}(300 \mathrm{~mL})+\mathrm{ST}$ & $9 \mathrm{~b}$ & $10 \mathrm{abc}$ & 60.0 & $242 \mathrm{a}$ & $4,072 \mathrm{a}$ \\
\hline $\mathrm{LI}(600 \mathrm{~mL})+\mathrm{ST}$ & $10 \mathrm{~b}$ & $12 \mathrm{abc}$ & 60.0 & $236 \mathrm{a}$ & $3,962 \mathrm{a}$ \\
\hline $\mathrm{LI}(1,200 \mathrm{~mL})+\mathrm{ST}$ & $12 \mathrm{a}$ & $16 \mathrm{ab}$ & 60.0 & $238 \mathrm{a}$ & $3,969 \mathrm{a}$ \\
\hline $\mathrm{CV}(\%)$ & 17.8 & 45.9 & 1.7 & 9.8 & 9.8 \\
\hline
\end{tabular}

(1) Peat inoculant was applied to the seed surface, according to the standard inoculation for the growing season, resulting in 300,000 cells seed ${ }^{-1}$ liquid inoculant was sprayed into the planting furrow at $300\left(300,000\right.$ cells seed $\left.^{-1}\right), 600$ and $1,200 \mathrm{~mL} \mathrm{ha}^{-1}$, in a final volume of $50 \mathrm{~L} \mathrm{ha}^{-1}$ (inoculant + water). Fungicides and micronutrients are described in the Materials and Methods section. ${ }^{(2)}$ Means $(n=6)$ in the same column followed by different letters are significantly different ( $\leq 50.05$, Fisher LSD test).

Table 4. Nodule number (NN) and dry weight (NDW) at the V4 stage, total N in shoots (TNS) at the R2 stage, total N grain content (TNG), and grain yield at the harvest of soybean inoculated with liquid inoculant on the seed (LIS) or in the furrow (LIF), with or without seed treatment (ST) with fungicides and micronutrients ${ }^{(1)}$. Experiment conducted in Londrina, Paraná, in the 2002/2003 growing season, in a soil with pre-established soybean/ Bradyrhizobium population $\left(1.1 \times 10^{4}\right.$ cells $\mathrm{g}^{-1}{\text { of soil })^{(2)}}^{(2)}$

\begin{tabular}{|c|c|c|c|c|c|}
\hline Treatment & NN & NDW & TNS & TNG & Yield \\
\hline & $\mathrm{N}^{0} /$ plant & $\mathrm{mg} / \mathrm{plant}$ & $\mathrm{mg} \mathrm{g}^{-1}$ & $\mathrm{~kg} \mathrm{ha-1} \mathrm{N}$ & $\mathrm{kg} \mathrm{ha} \mathrm{h}^{-1}$ \\
\hline Non-inoculated control & $13^{\mathrm{ns}}$ & $26 \mathrm{~b}$ & $98 \mathrm{~b}$ & $168 \mathrm{bc}$ & $2,841 \mathrm{ab}$ \\
\hline $\mathrm{N}$ control $\left(200 \mathrm{~kg} \mathrm{ha}^{-1} \mathrm{~N}\right)$ & 11 & $16 \mathrm{c}$ & $148 \mathrm{ab}$ & $156 \mathrm{c}$ & $2,652 \mathrm{~b}$ \\
\hline LIS & 16 & $38 \mathrm{a}$ & $170 \mathrm{a}$ & $181 \mathrm{ab}$ & $3,080 \mathrm{a}$ \\
\hline $\mathrm{LIS}+\mathrm{ST}$ & 14 & $34 \mathrm{ab}$ & $116 \mathrm{~b}$ & $192 \mathrm{a}$ & $3,113 \mathrm{a}$ \\
\hline LIF & 18 & $35 a b$ & $114 \mathrm{~b}$ & $191 \mathrm{a}$ & $3,029 \mathrm{a}$ \\
\hline $\mathrm{LIF}+\mathrm{ST}$ & 16 & $33 \mathrm{ab}$ & $109 \mathrm{~b}$ & $184 \mathrm{ab}$ & $3,003 \mathrm{a}$ \\
\hline $\mathrm{CV}(\%)$ & 28.8 & 33.5 & 23.3 & 12.0 & 11.8 \\
\hline
\end{tabular}

(1) Inoculant concentration to deliver 300,000 cells seed ${ }^{-1}$. Fungicides and micronutrients are described in the Materials and Methods section. ${ }^{(2)}$ Means $(n=6)$ in the same column followed by different letters are significantly different $(\mathrm{p} \leq 0.05$, Fisher LSD test). 


\section{Soils without pre-established Bradyrhizobium populations}

In 2000/01, in Avaré, São Paulo, all doses of liquid inoculant applied to the furrow as well as the standard peat inoculation, without fungicide seed treatment, resulted in significant $\mathrm{NN}$ increases compared to the non-inoculated and $\mathrm{N}$ control treatments (Table 5), although nodulation in all treatments was very low due to the occurrence of a dry spell after planting. No nodules were obtained when seeds were treated with $\mathrm{PI}$ and fungicides, confirming the toxic effects of the agrochemicals on the bacteria. These effects are even more noticeable in soils with no pre-established population of soybean/Bradyrhizobium, when unfavorable weather conditions affect the survival of the inoculated bacteria. Plants grown from seeds inoculated with the highest LI dose produced significantly more nodules than those from any other inoculant treatment, and the same trend was observed for NDW (Table 5). When seeds were treated with fungicides, the best performance for NGC was observed for the highest LI dose applied in the furrow. No significant differences were observed for grain yield or NGC. However, it is noteworthy that despite the dry spell observed during the experiment, the highest LI dose applied in-furrow promoted yield increases of 236 and $340 \mathrm{~kg} \mathrm{ha}^{-1}$ grain, when compared to the noninoculated and $\mathrm{N}$ fertilizer controls, respectively (Table 5).

In the following growing season, 2001/02, in Avaré, São Paulo, seed inoculation with PI resulted in significantly higher NN than in-furrow inoculation with any of the doses of LI tested, even though NDW was not significantly different from that obtained with the highest LI dose (Table 6). Once again, NN and
NDW of the plants of treatments with seed-treated PI or in-furrow LI were reduced in the presence of agrochemicals, when compared to the standard PI inoculation of untreated seeds, and the toxicity was only moderated under in-furrow inoculation with the highest LI dose. Only slight differences were observed between grain $\mathrm{N}$ contents. No significant differences were observed in TNG or grain yield, even though, once again, the yield under in-furrow inoculation with the highest LI dose was around $370 \mathrm{~kg} \mathrm{ha}^{-1}$ grain higher than the non-inoculated and the $\mathrm{N}$ controls (Table 6). However, due to severe dry conditions during this growth season, yields were very low.

In Jaciara, Mato Grosso, in 2000/01, all inoculant treatments resulted in significantly more nodules per plant than the non-inoculated and $\mathrm{N}$ controls, and the best response was obtained when seeds without fungicides or micronutrients were treated with peat inoculant (Table 7). Seed treatment with fungicides significantly reduced $\mathrm{NN}$ relative to the standard PI, even when inoculation was performed in the furrow, while NDW was significantly reduced only at the lowest LI dose applied in the furrow. As observed in the 2001/02 experiment, in Avaré, São Paulo, in general there were no differences among inoculant treatments for grain yield, but it is noteworthy that the very dry season had a higher negative impact on the $\mathrm{N}$ fertilizer treatment (Table 7).

Finally, in the experiment conducted in 2002/03, in Taciba, São Paulo, only LI was applied at a high concentration, equivalent to the highest dose tested in previous years, either to the seeds or in the furrow, and with or without seed treatment with fungicides. Both forms of inoculation significantly increased nodulation relative to the non-inoculated and $\mathrm{N}$

Table 5. Nodule number (NN) and dry weight (NDW) at the V4 stage, $\mathrm{N}$ grain content (NGC) at the R2 stage, total N grain content (TNG), and grain yield at the harvest of soybean inoculated with peat (PI) or liquid (LI) inoculant, with or without seed treatment (ST) with fungicides and micronutrients ${ }^{(1)}$. Experiment conducted in Avaré, São Paulo, in the 2000/2001 growing season, in a soil treated with inoculant for the first time $\left(<10^{1} \text { cells } \mathrm{g}^{-1} \text { of soil }\right)^{(2)}$

\begin{tabular}{|c|c|c|c|c|c|}
\hline Treatment & NN & NDW & NCG & TNG & Yield \\
\hline & $\mathrm{N}^{\mathrm{o}} /$ plant & $\mathrm{mg} /$ plant & $\mathrm{mg} \mathrm{g} \cdot 1$ & $\mathrm{~kg} \mathrm{ha}^{-1} \mathrm{~N}$ & $\mathrm{~kg} \mathrm{ha}^{-1}$ \\
\hline Non-inoculated control & $0.0 \mathrm{~d}$ & $0.2 \mathrm{ef}$ & 65 bcd & $180^{\mathrm{ns}}$ & $2,790^{\mathrm{ns}}$ \\
\hline $\mathrm{N}$ control $\left(200 \mathrm{~kg} \mathrm{ha}^{-1} \mathrm{~N}\right)$ & $0.0 \mathrm{~d}$ & $0.0 \mathrm{f}$ & $65 \mathrm{bcd}$ & 176 & 2,686 \\
\hline PI & $0.7 \mathrm{c}$ & $1.1 \mathrm{def}$ & $64 \mathrm{~cd}$ & 180 & 2,815 \\
\hline $\mathrm{PI}+\mathrm{ST}$ & $0.0 \mathrm{~d}$ & $0.0 \mathrm{f}$ & $63 \mathrm{~d}$ & 181 & 2,864 \\
\hline $\mathrm{LI}(150 \mathrm{~mL})+\mathrm{ST}$ & $1.0 \mathrm{c}$ & $1.4 \mathrm{de}$ & $64 \mathrm{~cd}$ & 180 & 2,804 \\
\hline $\mathrm{LI}(300 \mathrm{~mL})+\mathrm{ST}$ & $1.4 \mathrm{c}$ & $1.6 \mathrm{~cd}$ & $69 \mathrm{a}$ & 189 & 2,748 \\
\hline $\mathrm{LI}(600 \mathrm{~mL})+\mathrm{ST}$ & $1.3 \mathrm{c}$ & $2.5 \mathrm{bcd}$ & $67 \mathrm{abc}$ & 193 & 2,898 \\
\hline $\mathrm{LI}(1,200 \mathrm{~mL})+\mathrm{ST}$ & $2.6 \mathrm{~b}$ & $3.2 \mathrm{bc}$ & $67 \mathrm{abc}$ & 194 & 2,912 \\
\hline $\mathrm{LI}(2,400 \mathrm{~mL})+\mathrm{ST}$ & $4.2 \mathrm{a}$ & $6.7 \mathrm{a}$ & $68 \mathrm{ab}$ & 206 & 3,026 \\
\hline CV (\%) & 13.2 & 20.7 & 3.8 & 11.9 & 12.5 \\
\hline
\end{tabular}

(1) Peat inoculant was applied to the seed surface, according to the standard inoculation for the growing season, resulting in 300,000 cells seed ${ }^{-1}$; liquid inoculant was sprayed into the planting furrow at $150\left(300,000\right.$ cells seed $\left.^{-1}\right), 300,600,1,200$ and $2,400 \mathrm{~mL} \mathrm{ha}^{-1}$, in a final volume of $50 \mathrm{~L} \mathrm{ha}^{-1}$ (inoculant + water). Fungicides and micronutrients are described in the section Materials and Methods. ${ }^{(2)}$ Means $(n=6)$ in a same column followed by different letters differed significantly $(p \leq 0.05$, Fisher LSD test). 
controls, except when inoculant, fungicides, and micronutrients were combined as seed treatments
(Table 8). Seed treatment with agrochemicals significantly reduced NN and NDW when inoculation

Table 6. Nodule number (NN) and dry weight (NDW) at the V4 stage, $\mathrm{N}$ grain content (NGC), total N grain content (TNG), and grain yield at the harvest of soybean inoculated with peat (PI) or liquid (LI) inoculant, with or without seed treatment (ST) with fungicides and micronutrients ${ }^{(1)}$. Experiment conducted in Avaré, São Paulo, in the 2001/2002 growing season, in a soil treated with inoculant for the first time $\left(<10^{1} \text { cells } \mathrm{g}^{-1} \text { of soil }\right)^{(2)}$

\begin{tabular}{|c|c|c|c|c|c|}
\hline Treatment & NN & NDW & NCG & TNG & Yield \\
\hline & $\mathrm{N}^{\mathrm{o}} /$ plant & $\mathrm{mg} / \mathrm{plant}$ & $\mathrm{mg} \mathrm{g}^{-1}$ & $\mathrm{~kg} \mathrm{ha}^{-1} \mathrm{~N}$ & $\mathrm{~kg} \mathrm{ha} \mathrm{h}^{-1}$ \\
\hline Non-inoculated control & $0.3 \mathrm{e}$ & $10 \mathrm{~d}$ & $62.0 \mathrm{ab}$ & $92^{\mathrm{ns}}$ & $1,492^{\mathrm{ns}}$ \\
\hline $\mathrm{N}$ control $\left(200 \mathrm{~kg} \mathrm{ha}^{-1} \mathrm{~N}\right)$ & $0.3 \mathrm{e}$ & $2 \mathrm{~d}$ & $60.3 \mathrm{~b}$ & 90 & 1,488 \\
\hline PI & $21 \mathrm{a}$ & $68 \mathrm{a}$ & $60.0 \mathrm{~b}$ & 99 & 1,642 \\
\hline $\mathrm{PI}+\mathrm{ST}$ & $4 \mathrm{~d}$ & $32 \mathrm{c}$ & $60.0 \mathrm{~b}$ & 106 & 1,759 \\
\hline $\mathrm{LI}(300 \mathrm{~mL})+\mathrm{ST}$ & $5 \mathrm{~d}$ & $36 \mathrm{c}$ & $62.0 \mathrm{ab}$ & 99 & 1,614 \\
\hline $\mathrm{LI}(600 \mathrm{~mL})+\mathrm{ST}$ & $10 \mathrm{c}$ & $52 \mathrm{~b}$ & $61.2 \mathrm{ab}$ & 114 & 1,861 \\
\hline $\mathrm{LI}(1,200 \mathrm{~mL})+\mathrm{ST}$ & $14 \mathrm{~b}$ & $64 a b$ & $62.2 \mathrm{a}$ & 116 & 1,866 \\
\hline $\mathrm{CV}(\%)$ & 18.7 & 28.2 & 1.9 & 21.3 & 20.9 \\
\hline
\end{tabular}

(1) Peat inoculant was applied to the seed surface, according to the standard inoculation for the growing season, resulting in 300,000 cells seed ${ }^{-1}$; liquid inoculant was sprayed into the planting furrow at $300\left(300,000\right.$ cells seed $\left.^{-1}\right), 600$ and $1,200 \mathrm{~mL} \mathrm{ha}^{-1}$, in a final volume of $50 \mathrm{~L} \mathrm{ha}^{-1}$ (inoculant + water). Fungicides and micronutrients are described in the Materials and Methods section. ${ }^{(2)}$ Means $(n=6)$ in the same column followed by different letters are significantly different $(p \leq 0.05$, Fisher LSD test).

Table 7. Nodule number (NN) and dry weight (NDW) at the V4 stage, $\mathrm{N}$ grain content (NGC), total N grain content (TNG), and grain yield at harvest of soybean inoculated with peat (PI) or liquid (LI) inoculant, with or without with fungicides and micronutrients ${ }^{(1)}$ seed treatment (ST). Experiment conducted in Jaciara, Mato Grosso, in the 2001/2002 growing season, in a soil treated with inoculant for the first time $\left(<10^{2} \text { cells } \mathrm{g}^{-1} \text { of soil }\right)^{(2)}$

\begin{tabular}{|c|c|c|c|c|c|}
\hline Treatment & NN & NDW & NCG & TNG & Yield \\
\hline & $\mathrm{N}^{\mathrm{o}} /$ plant & $\mathrm{mg} /$ plant & $\mathrm{mg} \mathrm{g}^{-1}$ & $\mathrm{~kg} \mathrm{ha}{ }^{-1} \mathrm{~N}$ & $\mathrm{~kg} \mathrm{ha}{ }^{-1}$ \\
\hline Non-inoculated control & $5 \mathrm{~d}$ & $40 \mathrm{c}$ & $62.0 \mathrm{a}$ & $64^{\mathrm{ns}}$ & $1,027^{\mathrm{ns}}$ \\
\hline $\mathrm{N}$ control $\left(200 \mathrm{~kg} \mathrm{ha}^{-1} \mathrm{~N}\right)$ & $2 \mathrm{e}$ & $10 \mathrm{~d}$ & $61.0 \mathrm{abc}$ & 58 & 954 \\
\hline PI & $18 \mathrm{a}$ & $68 \mathrm{a}$ & $61.3 \mathrm{ab}$ & 71 & 1,157 \\
\hline $\mathrm{PI}+\mathrm{ST}$ & $10 \mathrm{~b}$ & $67 \mathrm{a}$ & $60.3 \mathrm{abc}$ & 72 & 1,193 \\
\hline $\mathrm{LI}(300 \mathrm{~mL})+\mathrm{ST}$ & $7 \mathrm{c}$ & $46 \mathrm{bc}$ & $62.0 \mathrm{a}$ & 67 & 1,080 \\
\hline $\mathrm{LI}(600 \mathrm{~mL})+\mathrm{ST}$ & $8 \mathrm{c}$ & $56 a b$ & $60.1 \mathrm{bc}$ & 60 & 1,003 \\
\hline $\mathrm{LI}(1,200 \mathrm{~mL})+\mathrm{ST}$ & $9 \mathrm{bc}$ & $61 \mathrm{a}$ & $60.0 \mathrm{c}$ & 66 & 1,095 \\
\hline $\mathrm{CV}(\%)$ & 16.7 & 20.4 & 1.7 & 25.3 & 25.2 \\
\hline
\end{tabular}

(1) Peat inoculant was applied to the seed surface, according to the standard inoculation for the growing season, resulting in 300,000 cells seed ${ }^{-1}$; liquid inoculant was sprayed into the planting furrow at $300\left(300,000\right.$ cells seed $\left.^{-1}\right), 600$ and $1,200 \mathrm{~mL} \mathrm{ha}^{-1}$, in a final volume of $50 \mathrm{~L} \mathrm{ha}^{-1}$ (inoculant + water). Fungicides and micronutrients are described in the Materials and Methods section. ${ }^{(2)}$ Means $(n=6)$ in the same column followed by different letters are significantly different ( $\mathrm{p} \leq 0.05$, Fisher LSD test).

Table 8. Nodule number (NN) and dry weight (NDW) at the V4 stage, total N in shoots (TNS) at the R2 stage, total $\mathrm{N}$ grain content (TNG), and grain yield at harvest of soybean inoculated with liquid inoculant on the seed (LIS) or in the planting furrow (LIF), with or without seed treatment (ST) with fungicides and micronutrients ${ }^{(1)}$. Experiment conducted in Taciba, São Paulo, in the 2002/2003 growing season, in a soil treated with inoculant for the first time $\left(<10^{1} \text { cells } \mathrm{g}^{-1} \text { of soil }\right)^{(2)}$

\begin{tabular}{|c|c|c|c|c|c|}
\hline Treatment & NN & NDW & TNS & TNG & Yield \\
\hline & $\mathrm{N}^{\mathrm{o}} /$ plant & $\mathrm{mg} /$ plant & $\mathrm{mg} \mathrm{g}^{-1}$ & $\mathrm{~kg} \mathrm{ha}^{-1} \mathrm{~N}$ & $\mathrm{~kg} \mathrm{ha} \mathrm{h}^{-1}$ \\
\hline Non-inoculated control & $0.2 \mathrm{c}$ & $1.7 \mathrm{c}$ & $125^{\mathrm{ns}}$ & $205 \mathrm{bc}$ & $3,560 \mathrm{bc}$ \\
\hline $\mathrm{N}$ control $\left(200 \mathrm{~kg} \mathrm{ha}^{-1} \mathrm{~N}\right)$ & $0.1 \mathrm{c}$ & $0.3 \mathrm{c}$ & 158 & $199 \mathrm{c}$ & $3,296 \mathrm{c}$ \\
\hline LIS & $14.1 \mathrm{~b}$ & $60.9 \mathrm{~b}$ & 100 & $232 \mathrm{abc}$ & $3,985 \mathrm{ab}$ \\
\hline $\mathrm{LIS}+\mathrm{ST}$ & $0.2 \mathrm{c}$ & $1.6 \mathrm{c}$ & 121 & $225 \mathrm{abc}$ & $3,870 \mathrm{ab}$ \\
\hline LIF & $26.0 \mathrm{a}$ & $118.8 \mathrm{a}$ & 149 & $250 \mathrm{a}$ & $4,244 \mathrm{a}$ \\
\hline $\mathrm{LIF}+\mathrm{ST}$ & $19.2 \mathrm{~b}$ & $79.7 \mathrm{~b}$ & 109 & $240 \mathrm{ab}$ & $4,036 \mathrm{ab}$ \\
\hline CV (\%) & 51.5 & 48.3 & 34.1 & 10.8 & 9.6 \\
\hline
\end{tabular}

(1) Inoculant concentration to deliver $1.2 \times 10^{6}$ cells seed ${ }^{-1}$. Fungicides and micronutrients are described in the Materials and Methods section. ${ }^{(2)}$ Means $(n=6)$ in the same column followed by different letters are significantly different $(\mathrm{p} \leq 0.05$, Fisher LSD test). 
was performed on the seed or in-furrow, compared to seeds that did not receive fungicides. Significant differences in TNG and grain yield were observed only when LIF of untreated seeds was compared to the non-inoculated and $\mathrm{N}$ controls (Table 8). Even though no significant differences were observed, all inoculation treatments resulted in higher mean yields than the non-inoculated and $\mathrm{N}$ control treatments.

\section{DISCUSSION}

To supply $\mathrm{N}$ to more productive cultivars, it is imperative that the population of selected rhizobial strains on the seed surface be increased (Hungria \& Vargas, 2000; Hungria et al., 2006a). Therefore, any factor that reduces the population of inoculated bradyrhizobia on the seed surface will have direct negative effects on the biological process.

Seed treatment with fungicides, in cases where genetic resistance is not available, is a generally accepted and recommended practice, so that today more than $90 \%$ of the soybean seeds in Brazil are treated with fungicides (Henning, 2004). Furthermore, combinations of systemic and contact fungicides have been employed to avoid problems of seedling emergence, and the number of active ingredients available has increased considerably (Henning et al., 1997; Embrapa, 2006; Hungria et al., 2007), which may have profound effects on the rhizobial population on the seeds.

Many authors have reported the negative effects of fungicides on soybean rhizobia (Pudelko \& Madrzak, 2004; Bikrol et al., 2005), as well as on rhizobia associated with other legumes, such as common bean (Phaseolus vulgaris L.) (Guene et al., 2003) - where seed treatment with fungicides was so toxic that no nodulation or $\mathrm{N}_{2}$ fixation was observed-and chickpeas (Cicer arietinum L.) (Aamil et al., 2005). The fungicide Mancozeb caused biochemical alterations and reduced growth rate and symbiotic properties of Bradyrhizobium sp. strain USDA 3187 (Fabra et al., 1998), while Captan induced biochemical alterations in the FAME and Biolog profiles of Rhizobium leguminosarum strain C1 (Dunfield et al., 2000). Biochemical changes induced by fungicides in cellular metabolism and fatty acid composition could have a direct negative effect on nodulation.

Most fungicides recommended for seed treatment in Brazil are highly toxic to the Bradyrhizobium strains present in the inoculants. The negative effects of the agrochemicals are even more pronounced when the crop is grown on sandy soils or planted under unfavorable climatic conditions (Hungria et al., 2006a, 2007). In our study, negative effects of agrochemicals on nodulation were observed in only one of the three experiments performed in areas with established
Bradyrhizobium populations. The absence of measurable effects of fungicides in these areas was expected, since toxicity is limited to the seed environment and further nodulation by the soil population occurs as the plants grow. However, agrochemicals resulted in no increase of soybean yield. On the other hand, the negative effects of seed treatment with agrochemicals in areas without established populations were clear, and occur because the inoculant strains on the seeds present at sowing represent the only rhizobium source. The results of our study reinforce the need to search for inoculation practices that can minimize the toxic effects of new formulas applied separately or as fungicidemicronutrient mixtures.

In-furrow inoculation at sowing with liquid or granular inoculants may decrease or even avoid damaging the fragile seed coats, and thus help overcome the adverse effects of seed treatment with pesticides, fungicides and other products with unknown compatibility with rhizobia. Besides, the risks of losing viable bacteria by seed drilling equipment or when the seed coat is lifted out of the ground during germination are reduced by this technique (Jauhri \& Subba Rao, 1989). Small-seeded legumes may also have an extra benefit from liquid in-furrow inoculation, by allowing the application of higher inoculum rates than is possible with seed inoculation (Brockwell, 1977).

In a study with soybean, even though nodulation occurred earlier in the case of seed inoculation, infurrow inoculation at sowing was as successful as the former (Brockwell et al., 1988). The authors attributed the earlier nodulation to the higher concentration of rhizobia in the vicinity of the seed, leading to a faster colonization of the rhizosphere than when rhizobia were distributed throughout the seedbed by liquid inoculation. Our results demonstrate that in-furrow inoculation of soybean may be as effective as the traditional seed inoculation, especially if higher doses of liquid inoculant are sprayed into the furrow. They clearly show that the in-furrow inoculation delivering high cell concentrations may surpass the toxicity caused by fungicide and micronutrient seed treatments. In our field trials, the most successful in-furrow inoculation rates in the presence of agrochemicals were those delivering at least $6 \times 10^{5}$ cells seed ${ }^{-1}$, and greater benefits, especially in firstyear areas, were obtained with increasing doses of up to $2.5 \times 10^{6}$ cells seed $^{-1}$.

Lanier et al. (2005) demonstrated that in experiments where peanut responded positively to inoculation, pod yield was higher when inoculant was applied in-furrow instead of to seeds. In addition, Díaz-Zorita \& Baliña (2004) Stated that in-furrow inoculation with Bradyrhizobium sp. is a practice recommended for high yields of peanut crops in sandy soils. 
As already mentioned, deleterious effects of fungicides are more pronounced in areas without preestablished populations of soybean/Bradyrhizobium and even more drastic in sandy soils. Under these conditions, in-furrow inoculation could be a viable alternative, as confirmed by the results of this study. Furthermore, in the case of adverse conditions at or after planting, the application of inoculant to the soil may improve the survival of the inoculated bacteria, since virtually any amount of inoculum can be applied (Burton, 1976), thus favoring nodulation of the lateral roots and increasing $\mathrm{N}_{2}$ fixation with soybean (Ciafardini \& Lombardo, 1991).

Another problem associated with the intensification of soybean cultivation is the depletion of the availability of some micronutrients in soils where they were not historically deficient (Campo et al., 2006). Since Mo and Co are essential for $\mathrm{N}_{2}$ fixation (Reisenauer, 1960; Kaiser et al., 2005), yield increases have been observed when these micronutrients are supplied to soybean growing in depleted soils (Albino \& Campo, 2001; Campo et al., 2006; Hungria et al., 2007). Seed treatment with Mo and Co salts has been recommended in Brazil, but the saline or acidic sources of micronutrients can damage the rhizobia (Bordeleau \& Prévost, 1994; Albino \& Campo, 2001), drastically affecting the survival of inoculated bacteria on the seeds, thus resulting in reduced nodulation and $\mathrm{N}_{2}$ fixation (Embrapa, 2006).

Consequently, the practice of in-furrow inoculation becomes an interesting alternative for soybean grown in soils where $\mathrm{Mo}, \mathrm{Co}$, and other micronutrients must be complemented. Our results show that although some toxic effects of seed-applied micronutrients are also observed when in-furrow inoculation is performed, the degree of toxicity is lower than when micronutrients are combined with fungicides and rhizobia and applied to the seeds.

Although direct soil application of inoculants has long been known in Brazil (Anonymous, 1898), it has not become a common practice for soybean inoculation. However, newly determined $\mathrm{N}$ requirements and seed treatment require other strategies and the results of our study show that in-furrow inoculation with high doses of liquid inoculant, allowing the delivery of an elevated number of inoculant cells, may provide an adequate population size of Bradyrhizobium, even under stressful soil and environmental conditions. In spite of the increase in the amount of inoculants to be applied per hectare, inoculation costs are very low and are compensated for by the yield increases. Furthermore, in-furrow inoculation proved to be a viable strategy to combine the need for inoculation with that for fungicide and micronutrient seed treatments.

\section{CONCLUSIONS}

1. In-furrow inoculation of soybean was as effective as the traditional seed inoculation both in areas with and without pre-established populations of Bradyrhizobium.

2. Inoculation always increased $\mathrm{N}$ accumulation in grain and/or the yield, and $\mathrm{N}$ fertilizer decreased both nodulation and yield. In areas growing soybean for the first time, seed treatments with agrochemicals affected nodulation when applied together with peat or liquid inoculant to the seeds.

3. In-furrow inoculation minimized the effects of seed treatment with agrochemicals.

4. The best results were obtained when Bradyrhizobium inoculum was applied at high levels, from at least $6 \times 10^{5}$ to up to $2.5 \times 10^{6}$ cells seed $^{-1}$ in the furrow.

5. In-furrow inoculation can be successful when soybean seeds need fungicide and micronutrient treatments prior to planting

\section{ACKNOWLEDGEMENTS}

This research was partially supported by the National Council of Scientific and Technological Development (CNPq, Brazil)/MAPA (577933/2008-6) and Research Fellowship (300698/2007-0). The authors are particularly indebted to Leny M. Miura (Embrapa Soja) for her help in several stages of this work, and Dr. Maria Cristina Neves de Oliveira for support with the statistical analyses.

\section{LITERATURE CITED}

AAMIL, M.; ZAIDI, A. \& KHAN, M.S. Fungicidal impact on chickpea-Mesorhizobium symbiosis. J. Environ. Sci. Health Part B, 39:779-790, 2005.

ALBINO, U.B. \& CAMPO, R.J. Efeito de fontes e doses de molibdênio na sobrevivência do Bradyrhizobium e na fixação biológica de nitrogênio em soja. Pesq. Agropec. Bras., 36:527-534, 2001.

ANDRADE, D.S. \& HAMAKAWA, P.J. Estimativa do número de células de rizóbio no solo e inoculantes por infecção em planta. In: HUNGRIA, M. \& ARAUJO, R.S., eds. Manual de métodos empregados em estudos de microbiologia agrícola. Brasília, Embrapa, 1994. p.63-94. 
ANONYMOUS. A vaccinação do solo. Bol. Inst. Agron. Campinas, 9:89-93, 1898.

BIKROL, A.; SAXENA, N. \& SINGH, K. Response of Glycine max in relation to nitrogen fixation as influenced by fungicide seed treatment. African J. Biotechnol., 4:667671, 2005.

BORDELEAU, L.M. \& PRÉVOST, D. Nodulation and nitrogen fixation in extreme environments. Plant Soil, 161:115125, 1994.

BROCKWELL, J. Application of legume seed inoculants. In: HARDY, R.W.F. \& GIBSON, A.H., eds. A treatise on dinitrogen fixation. Sydney, Wiley, 1977. p.277-309.

BROCKWELL, J.; GAULT, R.R.; HERRIDGE, D.F.; MORTHORPE, L.J. \& ROUGHLEY, R.J. Studies on alternative means of legume inoculation: Microbiological and agronomic appraisals of commercial procedures for inoculating soybeans with Bradyrhizobium japonicum. Austr. J. Agric. Res., 39:965-972, 1988.

BURTON, J. Problems in obtaining adequate inoculation of soybeans. Reprinted from WORLD SOYBEAN RESEARCH, Sept. 1976. 10p.

CAMPO, R.J.; ALBINO, U.B. \& HUNGRIA, M. Importance of molybdenum and cobalt to the biological nitrogen fixation. In: PEDROSA, F.O.; HUNGRIA, M.; YATES, G. \& NEWTON, W.E., eds. Nitrogen fixation: From molecules to crop productivity. The Netherlands, Springer, 2006. p.597-598.

CIAFARDINI, G. \& LOMBARDO, G.M. Nodulation, dinitrogen fixation, and yield improvement in second-crop soybean cover-inoculation with Bradyrhizobium japonicum. Agron. J., 83:622-625, 1991.

DÍAZ-ZORITA, M. \& BALIÑA, R. Respuesta de cultivos de maní a la inoculación con Bradyrhizobium sp. Ci. Suelo, 22:7-10, 2004.

DUNFIELD, K.E.; SICILIANO, S.D. \& GERMIDA, J.J. The fungicides thiram and captan affect the phenotypic characteristics of Rhizobium leguminosarum strain $\mathrm{C} 1$ as determined by FAME and Biolog analyses. Biol. Fert. Soils, 31:303-309, 2000.

EMPRESA BRASILEIRA DE PESQUISA AGROPECUÁRIA EMBRAPA. Tecnologias de produção de soja - Região Central do Brazil - 2007. Londrina/Planaltina/Dourados, Embrapa Soja/Embrapa Cerrados/Embrapa Agropecuária Oeste, 2006. 225p. (Sistemas de Produção 11)

FABRA, A.; ANGELINI, J.; DONOLO, A.; PERMIGIANI, M. \& CASTRO, S. Biochemical alterations in Bradyrhizobium sp USDA 3187 induced by the fungicide Mancozeb. Ant. Leeuwenhoek Int. J. Genet., 73:223-228, 1998.

FEHR, W.R. \& CAVINESS, C.E. Stages of soybean development. Ames, Iowa State University, 1977. (Special Report, 80)
GUENE, N.F.D.; DIOUF, A. \& GUEYE, M. Nodulation and nitrogen fixation of field-grown common bean (Phaseolus vulgaris) as influenced by fungicide seed treatment. African J. Biotechnol., 2:198-201, 2003.

HENNING, A.A. Patologia e tratamento de sementes: Noções gerais. Londrina, Embrapa Soja, 2004. 51p. (Embrapa Soja. Documentos, 235)

HENNING, A.A.; CAMPO, R.J. \& SFREDO, G.J. Tratamento com fungicidas, aplicação de micronutrientes e inoculação de sementes de soja. Londrina, Embrapa Soja, 1997. 7p. (Embrapa Soja. Comunicado Técnico, 58)

HUNGRIA, M. \& VARGAS, M.A.T. Environmental factors impacting $\mathrm{N}_{2}$ fixation in legumes grown in the tropics, with an emphasis on Brazil. Field Crops Res., 65:151-164, 2000.

HUNGRIA, M.; CAMPO, R.J.; MENDES, I.C. \& GRAHAM, P.H. Contribution of biological nitrogen fixation to the $\mathrm{N}$ nutrition of grain crops in the tropics: The success of soybean (Glycine max L. Merr.) in South America. In: SINGH, R.P.; SHANKAR, N. \& JAIWA, P.K., eds. Nitrogen nutrition and sustainable plant productivity. Houston, Studium Press, 2006a. p.43-93.

HUNGRIA, M.; CAMPO, R.J. \& MENDES, I.C. A importância do processo de fixação biológica do nitrogênio para a cultura da soja: Componente essencial para a competitividade do produto brasileiro. Londrina, Embrapa Soja, 2007. 80p. (Embrapa Soja. Documentos, 283)

JAUHRI, K.S. \& SUBBA RAO, N.S. Loss of inoculated rhizobial population due to epigeal germination of seed and the influence of methods of inoculation on soybean yield. Proc. Indian Acad. Sci. - Plant Sci., 99:29-35, 1989.

KAISER, B.N.; GRIDLEY, K.L.; NGAIRE BRADY, J.; PHILLIPS, T. \& TYERMAN, S.D. The role of molybdenum in agricultural plant production. Ann. Bot., 96:745-754, 2005.

LANIER, J.E.; JORDAN, D.L.; SPEARS, J.F.; WELLS, R. \& JOHNSON, P.D. Peanut response to inoculation and nitrogen fertilizer. Agron. J., 97:79-84, 2005.

PAVAN, M.A.; BLOCH, M.F.; ZEMPULSKI, H.D.; MIYAZAWA, M. \& ZOCOLER, D.C. Manual de análise química do solo e controle de qualidade. Londrina, Instituto Agronômico do Paraná, 1992. 40p. (Circular, 76)

PUDELKO, K. \& MADRZAK, C.J. Influence of fungicide Funaben $\mathrm{T}$ on nodulation of soybean [Glycine $\max (\mathrm{L}$. Merr.] in the field conditions. J. Plant Protect. Res., 44:155-159, 2004.

REISENAUER, H.M. Cobalt in nitrogen fixation by a legume. Nature, 186:375-376, 1960.

A VACCINAÇÃO do solo. Bol. Inst. Agron. Campinas, 9:89-93, 1898. 